\title{
PERBAIKAN SANITASI DAN HYGIENE PRODUK BANDENG PRESTO AR PUTRA MAJU JAYA DI DESA TEGAL ARUM, MOJOSONGO, SURAKARTA
}

\section{Raden Baskara Katri Anandito1, Siswanti', dan Lukita Purnamayati², Bara Yudhistira ${ }^{1}$}

\author{
1Fakultas Pertanian Universitas Sebelas Maret, J1. Ir. Sutami No.36A, Surakarta, 57126, \\ Indonesia. \\ ${ }^{2}$ Fakultas Perikanan dan Ilmu Kelautan Universitas Diponegoro, Jl. Prof. H. Soedarto, SH \\ Tembalang, Semarang, 50275, Indonesia. \\ Email: anandito_ito@yahoo.com
}

\begin{abstract}
Abstrak
Desa Tegal Arum merupakan salah satu daerah pengolah bandeng presto di Surakarta. Salah satu industri rumah tangga yang telah lama berjalan dengan usaha ini adalah IRT Bandeng presto milik Bapak Darpo dengan nama IRT “AR Putra Maju Jaya”. Usaha ini telah dirintis sejak tahun 2015, dengan kapasitas produksi mencapai empat kuintal tiap hari. Ikan bandeng segar yang digunakan didatangkan dari Gresik. IRT ini memiliki 4 karyawan yang bekerja 6 hari dalam 1 minggu. Banyaknya pengolah bandeng presto di Surakarta mengakibatkan persaingan usaha semakin tajam. Hal ini menyebabkan IRT mengalami kesulitan dalam memperluas daerah pemasaran sehingga pendapatan pun stagnan dan tidak mengalami peningkatan. Masalah utama yang terdapat pada IRT bandeng presto "AR Putra Maju Jaya" Bapak Darpo ini adalah masih rendahnya standar sanitasi dan hygiene proses pengolahan, peralatan yang digunakan masih terbatas dan sederhana sehingga kapasitas produksi maupun penyimpanan minimal, belum adanya kemasan yang baik sehingga produk kurang menarik dan mudah rusak. Solusi atas permasalahan tersebut adalah memperbaiki proses pengolahan bandeng presto dengan menerapkan standar sanitasi dan hygiene dengan menata ulang ruang produksi, membantu peralatan berbahan stainless steel, memperbaiki pengemasan produk dengan variasi pengemas dan desain kemasan serta tempat penyimpanan bahn baku dan produk yang memadai. Upaya tersebut diharapkan mampu meningkatkan kualitas bandeng presto AR Putra Maju Jaya sehingga dapat meningkatkan kapasitas produksi dan daerah pemasaran.
\end{abstract}

Katakunci: bandeng presto, sanitasi dan hygiene, pengemasan, kualitas

\footnotetext{
Abstract

Tegal Arum Village is one of the presto milkfish processing areas in Surakarta. One of the household industries that has been running for a long time with this business is Mr. Darpo's milkfish presto owned by the name IRT "AR Putra Maju Jaya". This business
} 
has been initiated since 2015, with production capacity reaching four quintals every day. Fresh milkfish used are imported from Gresik. This IRT has 4 employees who work 6 days a week. The high number of presto milkfish processors in Surakarta results in increasingly fierce business competition. This causes IRT to experience difficulties in expanding the marketing area so that income is stagnant and does not increase. The main problem found in the IRT milkfish presto "AR Putra Maju Jaya" Mr. Darpo is the still low standard of sanitation and hygiene processing, the equipment used is still limited and simple so that the production and storage capacity is minimal, there is no good packaging so the product is less attractive and easily damaged. The solution to these problems is to improve the presto milkfish processing by applying sanitation and hygiene standards by rearranging the production space, helping equipment made of stainless steel, improving product packaging with packaging variations and packaging design as well as adequate raw materials and product storage. The effort is expected to be able to improve the quality of AR Putra Maju Jaya's milkfish presto so that it can increase production capacity and marketing areas.

Keywords: milkfish presto, sanitation and hygiene, packaging, quality

\section{PENDAHULUAN}

Salah satu produk perikanan yang sering dikonsumsi oleh masyarakat adalah ikan bandeng. Bandeng merupakan suatu komoditas perikanan yang memiliki rasa enak dan gurih sehingga banyak digemari masyarakat. Berdasarkan data Susenas (Survey Sosial Ekonomi Nasional) BPS tahun 2016, tingkat konsumsi bandeng nasional rata-rata sebesar 1,40 kg/kapita dimana serapan pasar di tingkat rumah tangga di Provinsi Jawa tengah sebesar 50.916,96 ton (Kementrian Kelautan dan Perikanan, 2016).

Pada umumnya ikan bandeng diolah secara tradisional antara lain dengan cara pengasapan, penggaraman dan pemindangan. Pengolahan bandeng umumnya hanya mengubah komposisi dan tekstur daging, tetapi tidak dapat melunakkan durinya. Untuk mengatasi gangguan duri tersebut, maka bandeng diolah menjadi bandeng presto/duri lunak. Menurut
Astawan (2004), salah satu upaya untuk mengatasi hambatan dalam pemanfaatan ikan bandeng adalah mengolah ikan bandeng secara duri lunak. Di masyarakat, produk bandeng presto mulai meningkat jumlah produksinya. Hal ini dapat dilihat dengan semakin banyaknya industri rumah tangga yang bergerak di bidang pengolahan bandeng presto.

Salah satu daerah pengolah bandeng presto di Surakarta adalah Desa Tegal Arum, Kecamatan Mojosongo. Salah satu industri rumah tangga yang mengolah bandeng presto adalah IRT milik Bapak Darpo dengan nama IRT "AR Putra Maju Jaya". Usaha ini telah dirintis sejak tahun 2015, dengan kapasitas produksi mencapai empat kuintal tiap harinya.

Bahan baku berupa ikan bandeng segar yang digunakan untuk memproduksi bandeng presto didatangkan dari Gresik, Jawa Timur. IRT ini memiliki 4 karyawan yang bekerja 6 hari dalam 1 minggu. IRT menjual bandeng presto dengan cara 
menyetorkan ke penjual di pasar tradisional.

Banyaknya pengolah bandeng presto di Surakarta mengakibatkan persaingan usaha semakin tajam. Hal ini menyebabkan IRT mengalami kesulitan dalam memperluas daerah pemasaran sehingga pendapatan tidak mengalami peningkatan. Selain itu, seringkali produk bandeng presto tidak habis dalam satu hari sehingga harus disimpan sampai produk laku terjual. Produk bandeng presto akan mengalami kemunduran mutu selama penyimpanan, sehingga apabila produk tidak segera habis terjual maka IRT akan mengalami kerugian. Persaingan usaha bandeng presto juga didukung dengan tingkat pengetahuan konsumen yang semakin tinggi, sehingga semakin jeli dalam memilih produk.

Produk bandeng presto umumnya memiliki umur simpan yang pendek. Ikan bandeng yang diolah dengan proses presto, komposisi gizinya berubah dan lebih siap untuk dicerna. Oleh karena itu, bandeng presto mudah mengalami kerusakan terutama karena pertumbuhan mikrobia (Anonim, 2012).

Kualitas bandeng presto dipengaruhi oleh kualitas ikan bandeng segar, cara pengolahan, dan pengemasannya. Ikan bandeng segar yang diolah dengan baik akan menghasilkan produk bandeng presto dengan kualitas yang baik pula. Ikan bandeng segar mudah mengalami kerusakan terutama karena pertumbuhan mikrobia. Untuk menekan pertumbuhan mikrobia, diperlukan penanganan yang higienis, mulai dari penerimaan sampai pengolahannya.

IRT "AR Putra Maju Jaya" mendatangkan bahan bakunya dari Gresik, Jawa Timur. Perjalanan ikan bandeng segar dengan jarak yang jauh dari Gresik ke Surakarta dilakukan dengan sistem rantai dingin sehingga pada saat sampai di tempat tujuan ikan bandeng segar masih mempunyai kualitas yang baik. IRT "AR Putra Maju Jaya" terkadang mengurangi kapasitas produksinya apabila produk bandeng presto yang telah diproduksi tidak habis terjual. Hal ini mengakibatkan ikan bandeng segar yang dating dari Gresik tidak langsung diproduksi, sehingga harus disimpan pada suhu beku, sedangkan IRT belum mempunyai tempat penyimpanan yang memadai. Adapun tujuan dari pelaksanaan kegiatan ini untuk melakukan edukasi terkait dengan proses produksi pangan yang higienis, khususnya dalam produksi bandeng presto, yang diharapkan produk akhir bandeng presto akan meningkat kualitasnya.

\section{METODE}

Metode pengabdian dilakukan dengan penyuluhan dan pendampingan langsung terhadap mitra pengabdian. Program pengabdian berlangsung selama 6 bulan dari Apri-September 2019.

Adapun proses penyuluhan dilakukan dengan mengundang pemilik usaha beserta dengan pengusaha bandeng lain yang ada di daerah Mojosongo. Penyuluhan melibatkan Dosen dari Fakultas Pertanian UNS dan Fakultas Perikanan dan Ilmu Kelautan UNDIP. 


\begin{abstract}
Setelah penyuluhan pendampingan usaha, untuk memastikan konsistensi aplikasi proses produksi yang higienis oleh UKM. Pendampingan dilakukan dengan monitoring secara berkala dengan interval satu bulan untuk monitoring kepada mitra.
\end{abstract}

\section{HASIL DAN PEMBAHASAN}

\subsection{Pelaksanaan pengabdian}

\subsubsection{Penyuluhan dan pembinaan}

Kegiatan penyuluhan bertujuan agar para pelaku proses produksi bandeng presto mengerti dan memahami mengenai karakteristik bahan baku dan kualitas produk bandeng presto yang dihasilkan. Kegiatan penyuluhan yang disampaikan adalah sebagai berikut :

a. Penanganan dan kemunduran mutu ikan segar

b. Cara pengolahan ikan yang baik (GMP)

c. Sanitation Standard Operating Procedured (SSOP)

d. Pengemasan dan penyimpanan produk perikanan

\subsubsection{Pemberian bantuan peralatan}

Bantuan diberikan kepada IRT berupa peralatan penyimpanan bahan baku ikan segar (freezer), peralatan produksi (timbangan duduk, meja dan pisau stainless steel, panci presto), peralatan pengemasan dan penyimpanan (alat pengemas vakum, dan rak etalase kaca).

\subsubsection{Unjuk kerja}

Unjuk kerja dalam penataan kembali ruang produksi, memisahkan antara ruang produksi basah dan ruang produksi kering sesuai dengan desain lay out yang telah disusun.
Unjuk kerja ini dilakukan bersamasama dengan pihak mitra untuk mendesain ulang ruangan sesuai dengan tahapan proses pembuatan bandeng presto. Kegiatan ini juga dibantu oleh dua orang mahasiswa. Kegiatan ini juga bermanfaat untuk institusi dalam rangka membangun kerjasama dalam bidang praktek kerja lapangan ataupun magang mahasiswa.

\subsubsection{Pendampingan proses produksi dan praktek penggunaan alat \\ Pendampingan proses produksi} bertujuan untuk mendampingi IRT dalam mengolah produk bandeng presto sesuai dengan standar sanitasi dan hygiene dengan sekaligus praktek penggunaan peralatan yang diberikan oleh pelaksana kegiatan pengabdian kepada masyarakat kepada mitra dalam hal ini adalah IRT "AR Putra Maju Jaya". Selain itu juga dilakukan praktek penggunaan alat pengemas vakum dan penyimpanan produk. Kegiatan pendampingan proses produksi ini juga memberikan wawasan kepada mitra dalam rangka memperbaiki proses produksi dengan mengganti larutan garam setiap kali proses produksi dilaksanakan dan penggunaan bahan pewarna alami untuk memberikan warna pada bandeng presto. Tim pengabdian juga akan terus melakukan pendampingan sejak produksi, pengurusan perijinan produksi hingga pemasaran, untuk menjamin stabilitas dan kontinuitas usaha.

\subsubsection{Pelatihan pemasaran berbasis IT dan strategi direct selling \\ Dasar dari pelatihan pemasaran ini adalah pemanfaatan IT (Teknologi}


Informasi) dengan maraknya jejaring sosial yang tersedia. Banyaknya bisnis online serta banyaknya pengguna jejaring sosial membuat pemasaran produk di dunia maya menjadi salah satu cara yang efektif. Pelatihan pemanfaatan jejaring sosial facebook, pembuatan blog, serta pemasangan iklan dengan menampilkan produkproduk akan sangat membantu untuk perkembangan industri rumah tangga yang ada di Desa Tegalarum ini. Pemasaran dengan pemanfaatan IT ini sangat menguntungkan sebab produk tidak hanya dikenal di sekitar lingkungan IRT, tetapi mampu dikenali oleh masyarakat luas. Pelatihan ini akan berjalan apabila mitra mengetahui tentang bisnis online serta terampil dalam pengelolaan jejaring tersebut. Produk utama yang dipasarkan dengan IT adalah produk bandeng presto. Materi utama pada pelatihan ini adalah blog, web developing, dan pengelolaannya. Sedangkan untuk strategi direct selling yang utamanya akan disampaikan adalah motivasi dan teknik negosiasi.

\subsubsection{Pengujian nutrisi produk}

Analisis kimia dan mikrobiologi produk sangat dibutuhkan untuk mengetahui kualitas bandeng presto yang dihasilkan. Analisis kimia untuk mengetahui komposisi nutrisi produk, sedangkan analisis mikrobiologi untuk mengetahui cemaran yang ada pada produk. Pengujian nutrisi produk ini diharapkan mampu meningkatkan daya jual bandeng presto yang dihasilkan.

\subsection{Evaluasi Kegiatan}

Berdasarkan penyuluhan dan melihat kondisi dan permasalahan yang dihadapi mitra, maka Tim pengabdian menawarkan beberapa solusi dari permasalahan tersebut, antara lain:

\subsubsection{Menata kembali ruang produksi}

Proses penerimaan bahan baku sampai produk jadi. Untuk mendapatkan proses pengolahan yang memenuhi standar sanitasi dan hygiene, maka ruang produksi harus ditata sedemikian rupa sehingga alur proses menjadi jelas. Ruang produksi harus dijaga kebersihannya. Oleh karena itu, beberapa alat dihibahkan kepada mitra untuk bisa menghasilkan ruangan dengan proses produksi yang baik. Proses penataan ruang produksi ini telah dikoordinasikan dengan mitra dan telah dijadwalkan pada tanggal 5 September 2019.

\subsubsection{Beberapa alat yang diberikan}

a. Freezer

Pada proses penerimaan bahan baku, ikan bandeng yang datang tidak langsung diolah. Oleh karena itu, ikan harus dipertahankan suhunya sampai diolah, maka diperlukan es dalam jumlah yang banyak. Freezer yang diberikan diharapkan dapat membantu menghasilkan es yang dapat digunakan untuk mendinginkan ikan.

b. Palet plastik

Ikan yang dikeluarkan dari blong kemudian dilakukan penyiangan dan pencucian. Agar 
ikan tidak langsung dihamparkan di lantai, maka diberi palet plastik sehingga ikan dapat diletakkan di atas palet, kemudian dibersihkan. Air yang digunakan untuk membersihkan ikan dapat langsung menetes dan turun mengalir sehingga ikan tidak tergenang air. Hal ini dapat mengurangi pencemaran mikrobia pada ikan. Selain ituk proses penyiangan dan pencucian, palet plastik juga digunakan untuk meletakkan papan kayu untuk mengemas bandeng presto dan produk akhir agar tidak langsung diletakkan di lantai dan menempel dinding ruangan.

Selain itu diberikan bantuan alat yang menunjang proses produksi. Timbangan yang diberikan dapat digunakan untuk menggantikan timbangan lama sehingga membantu mengurangi pencemaran produk. Kompor yang diberikan dapat digunakan untuk menggantikan kompor yang telah rusak sehingga proses presto dapat berjalan lancer dengan adanya dua panci presto yang dapat beroperasi.

Pengemas vakum dapat digunakan untuk diversifikasi pengemas dan bertujuan agar produk yang dihasilkan lebih tahan lama sehingga diharapkan mitra dapat memperluas daerah pemasaran karena produk tahan selama distribusi pada suhu ruang. Berdasarkan Paputungan et al. (2015) menunjukkan bahwa penyimpanan ikan cakalang asap utuh dengan menggunakan plastik vakum lebih dapat mempertahankan kualitas ikan cakalang asap utuh pada penyimpanan suhu ruang dibandingkan ikan cakalang asap utuh tanpa pengemasan vakum.

\subsubsection{Sosialisasi penggunaan alat pengemas vakum}

Penggunaan alat pengemas vakum dimaksudkan untuk memberikan umur simpan yang lama pada produk. Operasional pengemas vakum memerlukan keterampilan khusus, sehingga dilakukan sosialisasi penggunaan alat tersebut.

\subsubsection{Desain kemasan}

Proses diversifikasi pengemas bandeng presto diperlukan desain kemasan yang menarik antara lain pada kemasan plastik dan kardus yang digunakan. Saat ini desain kemasan masih dalam tahap pengerjaan. Desain ini akan diberikan kepada mitra pada saat sosialisasi penggunaan alat pengemas vakum.

\subsubsection{Pengujian nutrisi produk}

Analisa nutrisi pada bandeng presto yang diproduksi diperlukan untuk mengetahui secara pasti komponen gizi yang terkandung pada produk. Analisa tersebut dilakukan di laboratorium program studi Ilmu dan Teknologi Pangan UNS.

\subsubsection{Pemasaran berbasis IT}

Penyuluhan pemasaran berbasis IT dilakukan dengan membuat akun sosial media yang dapat dilakukan sebagai media promosi produk. Adapun media tersebut yaitu facebook, instagram, dan shopee. 


\subsubsection{Saran}

Perlu adanya inovasi produk lain untuk mengembangkan pasar berbasis olahan bandeng, adapun pilihannya dapat berupa produk kering seperti karaka tau kerupuk. Dalam Yudhistira (2019), penambahan ikan dapat meningkatkan protein karak. Pengembangan karak ikan dapat menjadi alternatif produk pendamping bandeng presto.

\section{KESIMPULAN}

Kegiatan pengabdian telah meningkatkan aspek pemasaran dan pendapatan mitra.

\section{DAFTAR PUSTAKA}

Angela, G. C., Mentang, F., dan Sanger, G. 2015. Kajian mutu ikan cakalang (Katsuwonus pelamis, L.) asap dari tempat pengasapan Desa Girian atas yang dikemas vakum dan non vakum selama penyimpanan dingin. Jurnal Media Teknologi Hasil Perikanan, 3(2), 29-40.

Anonim. 2012. Umur Simpan Bandeng Presto (Pressure Cooked Milkfish).

http:/ / hiubandengpresto.blogs pot.com/2012/05/umursimpan-bandeng-prestopressure.html. Diakses Agustus 2018.

Astawan, M. 2004. Ikan yang Sedap dan Bergizi. Tiga Serangkai, 45 hal.

Kementrian Kelautan dan Perikanan. 2016. Profil Komoditas Ikan Bandeng. http://www.wpi.kkp.go.id/in dex.php/berita/146-profil- komoditas-ikan-bandeng. Diakses 15 Agustus 2018.

Paputungan, T. S., Wonggo, D., dan Damongilala, L. J. 2015. Kajian mutu ikan cakalang (Katsuwonus pelamis L.) asap utuh yang dikemas vakum dan non vakum selama proses penyimpanan pada suhu ruang. Jurnal Media Teknologi Hasil Perikanan, 3(2), 66-71.

Rahmadana. 2013. Analisa Masa Simpan rendang Ikan Tuna dalam Kemasan Vakum Selama Penyimpanan pada Suhu Ruang dan Dingin. Skripsi. Jurusan Teknologi Pertanian Universitas Hasanuddin. Makassar.

Yudhistira, B., Affandi, D R., Artika, Y K P. 2019. Prosiding IOP Conf. Series: Earth and Environmental Science 246 (2019) 012047, 1-6. 